\title{
Trichostatin A inhibits radiation-induced epithelial-to- mesenchymal transition in the alveolar epithelial cells
}

\author{
Devipriya Nagarajan ${ }^{1,2}$, Lei Wang ${ }^{1}$, Weiling Zhao ${ }^{1,3}$ and Xiaochen Han ${ }^{3}$ \\ ${ }^{1}$ Department of Radiation Oncology, Wake Forest School of Medicine, Winston-Salem, NC, USA \\ ${ }^{2}$ School of Chemical \& Biotechnology, SASTRA University, Thanjavur, Tamil Nadu, India \\ ${ }^{3}$ Tangshan People's Hospital, Tangshan, Hebei, China \\ Correspondence to: Weiling Zhao, email: wzhao@wfubmc.edu \\ Xiaochen Han, email: rmyy_hxc@163.com
}

Keywords: TSA; EMT; TGF-beta; radiation; HDAC

Received: September 14, $2016 \quad$ Accepted: August 29, $2017 \quad$ Published: October 09, 2017

Copyright: Nagarajan et al. This is an open-access article distributed under the terms of the Creative Commons Attribution License 3.0 (CC BY 3.0), which permits unrestricted use, distribution, and reproduction in any medium, provided the original author and source are credited.

\section{ABSTRACT}

Radiation-induced pneumonitis and fibrosis are major complications following thoracic radiotherapy. Epithelial-to-mesenchymal transition (EMT) plays an important role in tissue injury leading to organ fibrosis, including lung. Our previous studies have reported that radiation can induce EMT in the type II alveolar epithelial cells in both in vitro and in vivo. HDAC inhibitors are a new family of anti-cancer agents currently being used in several clinical trials. In addition to their intrinsic anti-tumor properties, HDAC inhibition is also important in other human diseases, including fibrosis and radiation-induced damage. In this study, we evaluated the effect of Trichostatin $A$ (TSA), a HDAC inhibitor, on radiation-induced EMT in type II alveolar epithelial cells (RLE-6TN). Pre-treatment of RLE-6TN cells with TSA inhibited radiation-induced EMTlike morphological alterations including elevated protein level of a-SMA and Snail, reduction of E-cadherin expression, enhanced phosphorylation of GSK3 $\beta$ and ERK1/2, increased generation of ROS. Radiation enhanced the protein level of TGF- $\beta 1$, which was blocked by $\mathrm{N}$-acetylcysteine, an antioxidant. Treating cells with SB-431542, TGF- $\beta 1$ type I receptor inhibitor, diminished radiation-induced alterations in the protein levels of $p$-GSK-3 $\beta$, Snail-1 and a-SMA, suggesting a regulatory role of TGF- $\beta 1$ in EMT. Pre-incubation of cells with TSA showed significant decrease in the level of TGF- $\beta 1$ compared to radiation control. Collectively, these results demonstrate that i] radiation-induced EMT in RLE-6TN cells is mediated by ROS/MEK/ERK and ROS/ TGF- $\beta 1$ signaling pathways and ii] the inhibitory role of TSA in radiation-induced EMT appears to be due, at least in part, to its action of blocking ROS and TGF- $\beta 1$ signaling.

\section{INTRODUCTION}

Thoracic radiotherapy, either using X-rays or similar rays, is one of the successful treatment modes for lung and breast cancers. In lung cancer cases, $60 \%$ of patients receive radiation treatment either alone or in combination with surgery/chemotherapy [1]. The lung complications, including pneumonitis and fibrosis develop within month to years after treatment with radiotherapy thereby affects survival of cancer patients
[2]. Myofibroblasts plays important role in fibrosis and upon activation, cells synthesize and stimulates deposition of extracellular matrix (ECM) proteins; however, recent studies focuses on epithelial cells which have ability to convert themselves into myofibroblast by a process called "epithelial-mesenchymal transition (EMT)" and it has been reported in idiopathic pulmonary fibrosis and experimental fibrosis [3, 4]. During EMT, epithelial cell loses its polarity gradually and acquires mesenchymal features with enhanced migratory potential [5]. 
$\alpha$-SMA, a mesenchymal protein, is released in response to myofibroblast activation and confers strong contractile properties [6]. E-cadhein is an epithelial marker involved mainly in maintenance of cell-cell interaction and preserves structural integrity of the cell [7]. Snail, a master regulator of E-cadherin, helps epithelial cells to develop into fibroblast-like migratory mesenchymal cells [8].

Early studies indicate that TGF- $\beta$ can partially mediate EMT through a network of signaling and transcriptional events [9, 10]. In addition to TGF-beta signaling pathways other molecules like Rho, Ras, ERK, MAPK, Wnts, NFkappaB and PI3K has been reported to enhance EMT [11]. Our in vivo studies also suggested that $\mathrm{FVB} / \mathrm{N}$ mice upon exposure to thoracic radiation (single and fractionated) are highly sensitive to radiation and EMT might play a inter-mediatory role towards development of lung fibrosis $[12,13]$. Previously, we reported that radiation stimulated EMT via ERK/GSK3s/Snail pathway in RLE-6TN cells (alveolar type II epithelial cells) [13].

Trichostatin A (TSA) is an effective inhibitor of Histone deacetylases (both class I and class II) and is isolated from Sterptomyces sp. as a fermentation product $[14,15]$. TSA effectively inhibits cell cycle arrest and has been used in clinical trial for the treatment of cancer $[16,17]$. On the other hand, it has been considered as a effective agent against fibrogenic diseases including liver fibrosis and cutaneous radiation syndrome [18-20]. TSA has been reported to decrease EMT induced by TGF $\beta 2$ and thereby prevents the migratory potential of lens epithelial cells [21]. However, the role of TSA on gamma radiation induced alveolar EMT is not clearly investigated. In the present study, we tried to i] understand the role

$\mathbf{A}$
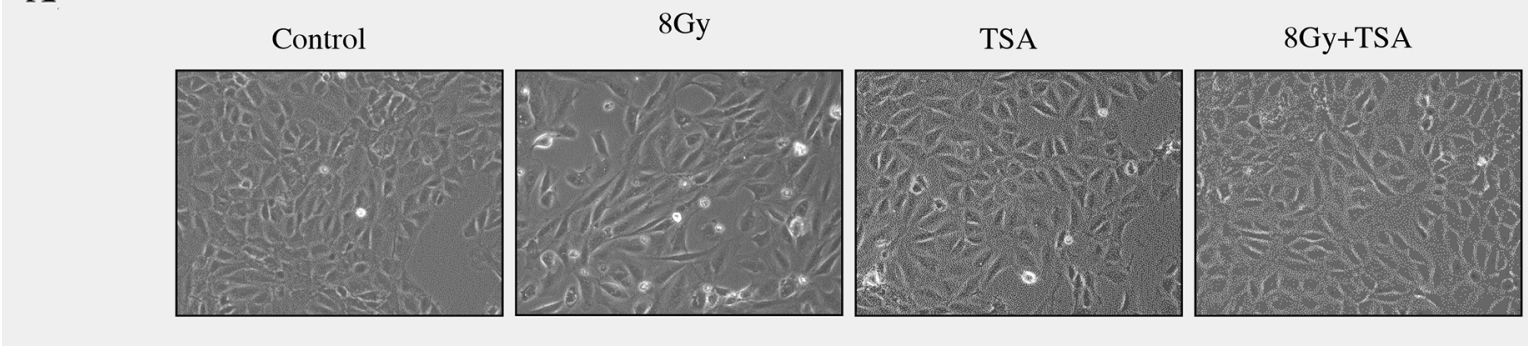

B

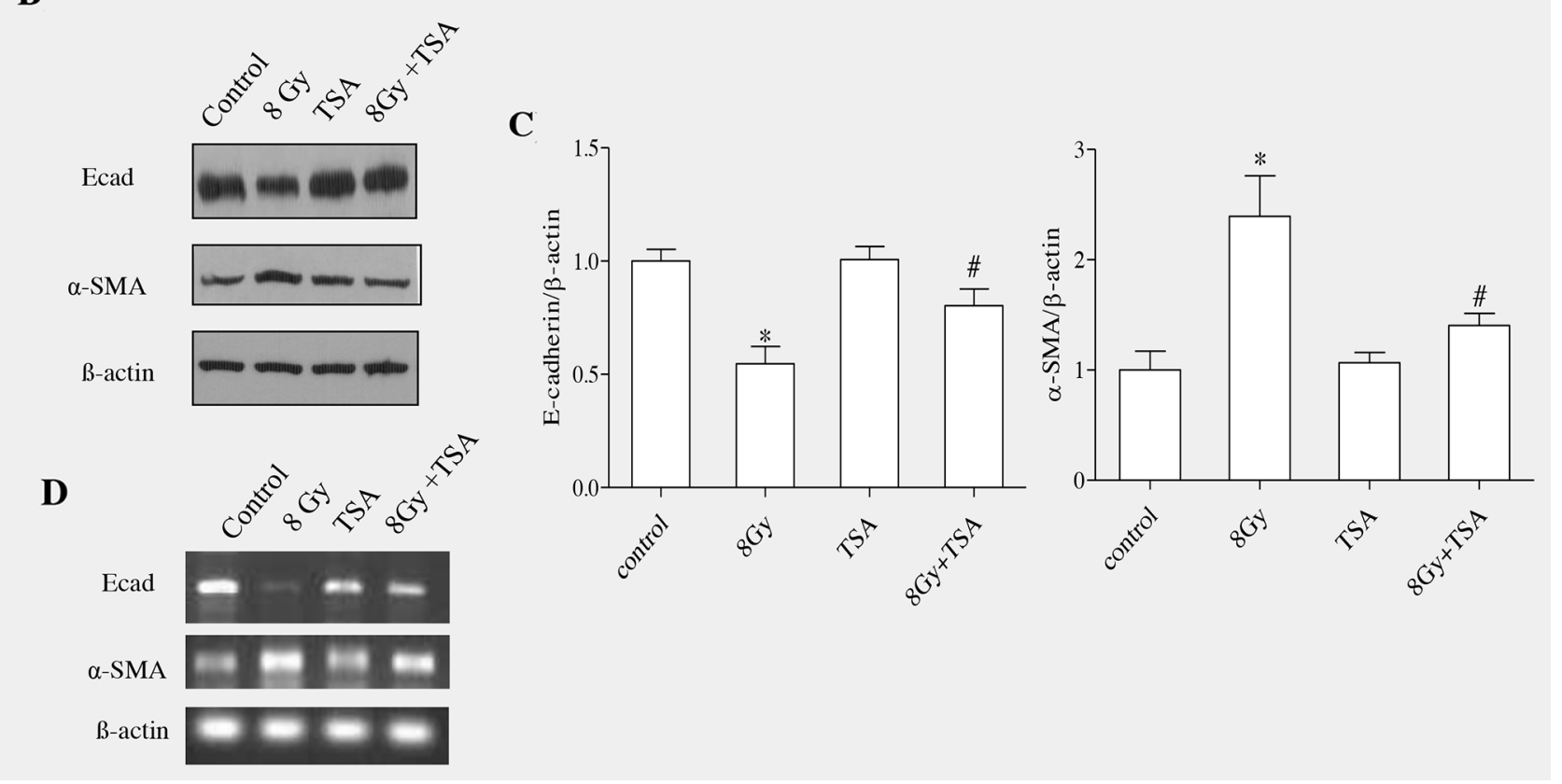

Figure 1: TSA inhibits EMT induced by irradiation in RLE-6TN cells. (A) RLE-6TN cells were grown to 60\% confluency in tissue culture plates and treated with TSA $(100 \mathrm{nM})$ for $2 \mathrm{~h}$ followed by radiation treatment at the dose of $8 \mathrm{~Gy}$. Images were captured at the magnification of 200X using inverted microscope and representative morphological changes are shown. (B) The protein levels of E-cadherin and $\alpha$-SMA were determined using western blot analysis at $72 \mathrm{~h}$ post-treatment with radiation and/or. (C) Densitometric analysis of the Western blot results from B. Data are mean \pm SEM; $n=3 ;{ }^{*} p<0.05$ vs. non-irradiated control; ${ }^{*} p<0.05$ vs. irradiated control. The same amounts of total protein are loaded in each lane. (D) RT-PCR analysis of E-cadherin mRNA and $\alpha$-SMA in the cells collected at $72 \mathrm{~h}$ postirradiation. 
of TSA on gamma radiation-induced EMT in alveolar epithelial cells (RLE6TN and A549); ii] analyse cell signaling events involved in inhibitory effect of TSA on radiation-induced EMT.

\section{RESULTS}

\section{TSA reversed EMT in irradiated rat alveolar epithelial cells (RLE-6TN cells)}

The morphological changes induced by radiation on RLE-6TN cells have been reported previously from our lab. We observed that radiation promoted loss of cell-cell contacts in RLE-6TN and converted their structures from cuboidal to a spindle shaped fibroblastic phenotype [13]. To know the effect of TSA on morphological changes induced by radiation, we treated RLE-6TN cells with 100nM TSA prior to irradiation (single dose; 8Gy) and recorded morphologic changes of alveolar cells after $72 \mathrm{~h}$.
Untreated RLE-6TN cells showed a cobblestone epithelial morphology and cell-cell contacts were clearly observed. But irradiated cells displayed lose of cell-cell contacts and showed more elongated spindle shaped morphology. However, pre-treatment with TSA effectively protected the epithelial cells from radiation-induced morphological changes. TSA alone treated cells did not alter the epithelial architecture of RLE-6TN cells (Figure 1A). At molecular level, EMT enhanced the expression of mesenchymal proteins (Snail, alphaSMA) and reduced expression of epithelial proteins (E-cadherin) [7].

We next investigated the role of TSA on the level of E-cadherin and $\alpha$-SMA in RLE6TN cells, which were harvested at $72 \mathrm{~h}$ post irradiation. As E-cadherin is an epithelial marker and $\alpha$-SMA is a mesenchymal protein [13], in our study we evaluated both proteins using western blot analyses. Radiation (8Gy) markedly reduced the protein and gene expression of epithelial marker and also enhanced mesenchymal marker in
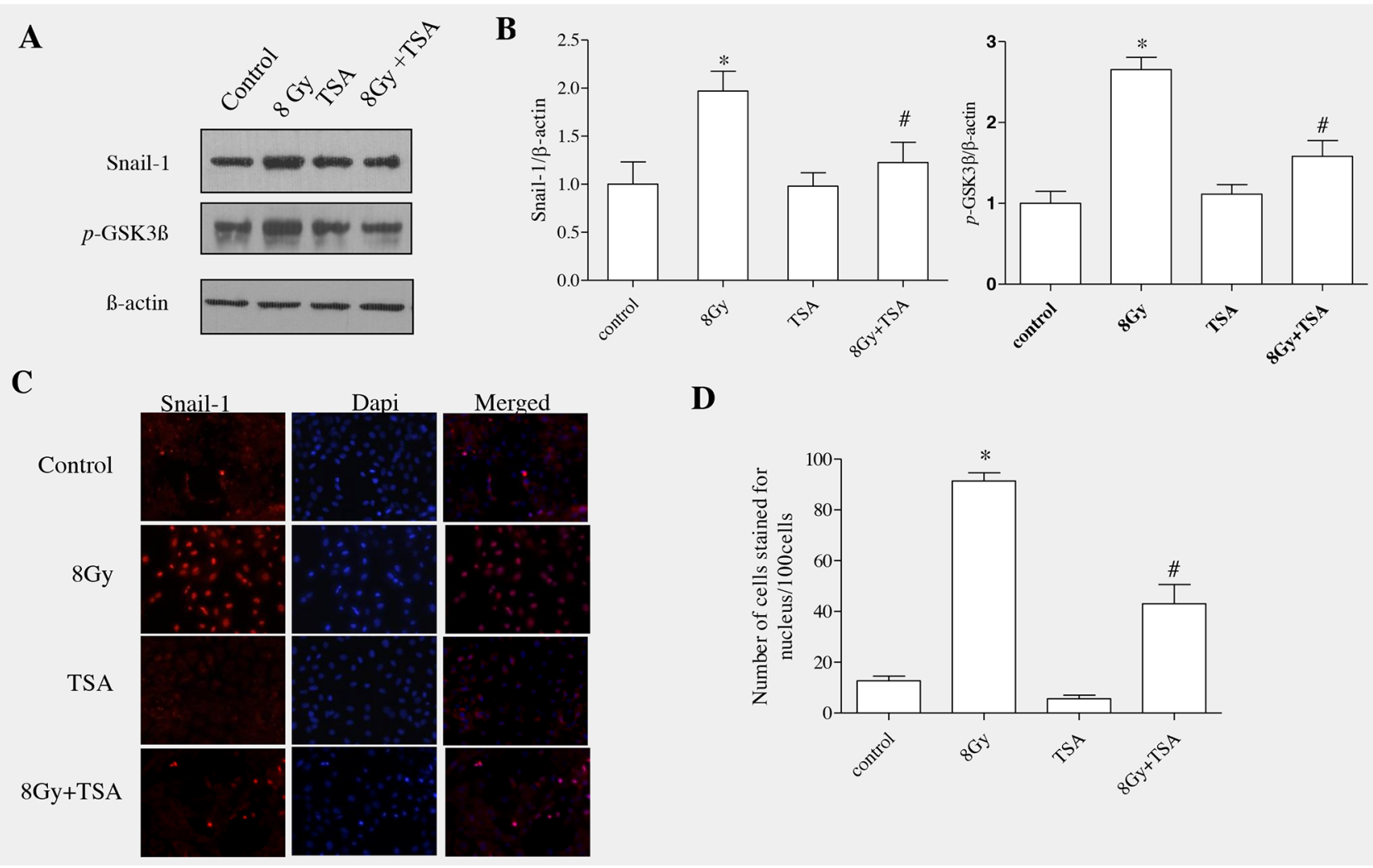

$\mathbf{D}$

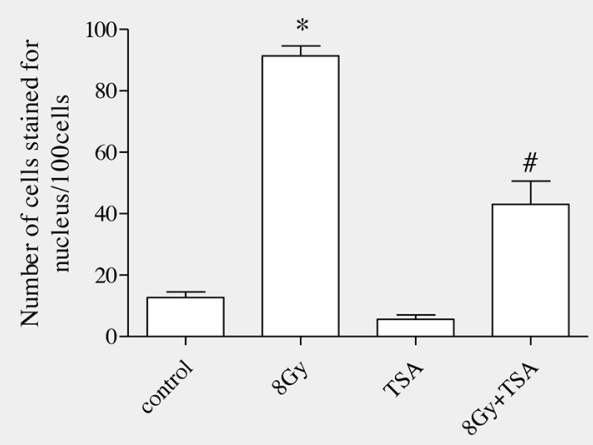

Figure 2: TSA reduced Snail activation and inhibited the phosphorylation of GSK3 $\beta$ in irradiated RLE-6TN cells. RLE6TN cells were irradiated with 8 Gy of ${ }^{137} \mathrm{Cs} \gamma$ rays, protein samples were collected at 7 h post-irradiation and analysed using western blot for Snail and GSK3 $\beta(\mathrm{pSer} 9)$. (A) Shows the representative blot of Snail and GSK3 $\beta(\mathrm{pSer} 9)$ in RLE-6TN cells. (B) Shows densitometric quantification of Snail and GSK3 $\beta$ (pSer9); data are mean \pm SEM; $n=3 ;{ }^{*} p<0.05$ vs. non-irradiated control; ${ }^{\#} p<0.05$ vs. irradiated control. (C) RLE-6TN cells was examined by immunofluorescence for staining of Snail (red) and Dapi (blue) in untreated and treated cells at $7 \mathrm{~h}$ postirradiation $(400 \mathrm{X})$. Merged images of Snail and DAPI showed that radiation enhanced the nuclear colocalization of Snail where as TSA-pretreatment decreased the nuclear localization of Snail in comparison with radiation treatment. (D) Positively stained cells were identified using fluorescence microscope in 10 high-power fields. Quantification was determined by counting five different fields per assay. The number of cells stained for nucleus was calculated as the average of five different fields in each sample. The data were statistically analyzed from three independent experiments using one-way ANOVA. 
alveolar epithelia cells (Figure 1B and 1D). However, TSA led to a significant modification in the protein and gene expressions of both E-cadherin and $\alpha$-SMA in cells collected at $72 \mathrm{~h}$ after irradation (Figure 1B and 1D). Densitometric analysis of the Western blotting results obtained from three independent experiments showed that TSA treatment before irradiation enhanced enhanced the level of E-cadherin up to $85 \%$ and reduced $\alpha$-SMA level to near normal (Figure 1C). TSA treatment alone did not induce any changes in the protein and gene expression of E-cadherin and $\alpha$-SMA when compared to those from the untreated cells. Thus, morphological observations together with alteration in the epithelial and mesenchymal markers suggested that TSA treatment effectively inhibited the epithelial cells to undergo transition into mesenchymal phenotype when exposed to radiation at dose of $8 \mathrm{~Gy}$.

\section{TSA inhibited the activation of snail and phosphorylation of GSK3 $\beta$}

Snail binds specifically to the promoter region of E-cadherin gene and represses its transcription; thereby snail act as an important transcriptional regulator of EMT. We next examined the effect of TSA on Snail protein in alveolar epithelial cells. RLE-6TN cells were incubated with TSA (100nM) for $2 \mathrm{~h}$ and cells were exposed to radiation (8Gy). The cells were then harvested at $7 \mathrm{~h}$ to determine the level of snail protein in all the groups. As shown in the Figure 2A, Snail was significantly increased in irradiated group which was effectively modulated by the treatment of TSA, as we observed from the data of western blot (Figure 2A). The mean fold change was analysed using densitometric analysis and it showed that there was decrease in the Snail protein level in control, TSA and also TSA+radiation groups $(1.0 \pm 0.23,0.98 \pm 0.14$ and $1.22 \pm 0.21$, respectively when compared with irradiated cells where the levels was $1.97 \pm 0.21$ (Figure 2B).

Normally in cells, accumulation of Snail is controlled mainly by GSK3 $\beta$ (glycogen synthase kinase 3 $\beta$ ) which tightly binds and phosphorylates Snail protein. Upon phosphorylation, Snail undergoes ubiquitination which ultimately leads to proteasomal degradation [23]. GSK-3 $\beta$ activity has been known to be necessary for maintaining the epithelial architecture. GSK3 $\beta$ activity is upregulated or downregulated depending on the phosphorylation site of aminoacid. It is upregulated when phosphorylation ocurrs at tyrosine-216; it is downregulated when phosphorylation occurs at N-terminal of serine-9 residue [24]. In our previous study, Western blot analysis on total GSK-3 $\beta$, GSK-3 $\beta$ (pTyr216) and GSK-3 $\beta$ (pSer9 showed that radiation stimulated the inactive form of GSK3 $\beta$ (pser9), whereas the total GSK-3 $\beta$ and active form GSK-3 $\beta$ (pTyr216) remained unchanged [13]. Our current data showed that there was increased expression of pGSK $3 \beta$ (ser9) in irradiated group which was effectively modulated upon TSA pre-treatment (Figure 2A and 2B).
GSK3 $\beta$ is well known to regulate Snail expression and activation by mainly inhibiting its i] transcription; ii] stimulating its degradation and iii] preventing nuclear translocation [25]. Therefore, inhibition of GSK-3 $\beta$ function results in an increased expression of Snail and its translocates into nucleus where it becomes functionally active to stimulate EMT markers.

RLE-6TN cells were seeded onto 8-well chamber slides and immunofluorescence analysis was performed to know the effect of TSA on nuclear translocation of Snail. Our results showed that irradiation enhanced the nuclear translocation of Snail at $7 \mathrm{~h}$, whereas pretreatment with TSA reduced the radiation-induced changes (Figure 2C and 2D). Altogether, our data showed that TSA prevented GSK-3 $\beta$ inactivation and Snail accumulation/nuclear translocation in the irradiated cells, indicating that TSA played an inhibiting role in the key transcription factor of EMT induced by irradiation.

\section{TSA inhibited radiation-induced ERK activation and ROS formation in alveolar epithelial cells}

The activation of GSK3 $\beta$ can be controlled by various mechanisms, however, phosphorylation of GSK $3 \beta$ via protein kinases play a crucial role in regulation. In our earlier study, our data suggested that ERK actively involved in inhibiting GSK-3 $\beta$ by phosphorylating at ser-9 residue during radiation-induced EMT in alveolar epithelial cells [13]. We analyzed the effect of TSA on ERK activation at $15 \mathrm{~min}$ of post irradiation in alveolar epithelial cells.

Western blot analysis and and densitometric quantification showed that preincubation of cells with TSA for $2 \mathrm{~h}$ reduced phosphorylated ERK protein levels when compared to irradiated group (Figure 3A and 3B). ROS act as a important signalling mediator during radiation induced EMT by activating ERK/GSK3 $\beta /$ Snail pathway in rat alveolar epithelial cells, as we reported previously [13], thus we aimed to understand whether TSA can modulate radiation-induced oxidative stress in alveolar epithelial cells. For that, 100nM of TSA was incubated $2 \mathrm{~h}$ before irradiation (8Gy) in rat alveolar epithelial cells and ROS formation was measured using DCFH-DA assay [26]. As shown in Figure 3C, TSA effectively decreased the ROS formation when compared to the radiation control. (Figure 3C). These data indicate that TSA may act as an antioxidant to inhibit ROS production induced by radiation.

\section{Irradiation did not alter the levels of HDAC proteins in the RLE-6TN cells}

Histone deactylases (HDACs) are enzymes that remove acetyl groups from lysine aminoacid in histone and also in many non histone proteins [27-29]. Based on homology, HDACs can be categorized into four different 
classes: Class I: HDAC1,2,3 and 8; Class II: 4,5,6,7,9 and10; Class III: Sirtunins in mammals and Sir2 in yeast; Class IV: HDAC11 [30, 31], sirtuins in mammals and Sir2 in yeast belong to class III and HDAC11 belong to class IV. As, HDACs have been shown to be involved in fibrogenesis in various organs, we expected that radiation would modulate HDAC levels in rat alveolar epithelial cells. Epithelial cells (RLE6TN) were exposed to radiation (8Gy) and were harvested at different time points $\left(15^{\prime}, 30\right.$ ', $1 \mathrm{~h}, 3 \mathrm{~h}$ and $7 \mathrm{~h}$ ). Western blot analysis (Figure 4A and 4B) showed that radiation didnot alter the protein levels of HDACs in irradiated RLE6TN cells in comparison with non-irradiated controls. These data indicate that radiation doesn't alter the expression of HDACs in these lung epithelial cells.

\section{TSA inhibited radiation-induced increase in TGF- $\beta$ and CTGF proteins in RLE-6TN cells}

TGF- $\beta 1$ has been well reported to stimulate EMT in various cells including mammary epithelial cells, renal proximal tubular, lens and alveolar epithelial cells [32-35]. To determine whether TGF $\beta 1$ acts as a mediator in radiation -induced EMT in alveolar epithelial cells, TGF $\beta 1$ protein levels were collected and estimated at different time points (15min to $7 \mathrm{~h}$ ) in irradiated RLE6TN cells using Western blot analysis. The results showed that the levels of TGF $\beta 1$ were gradually increased with increase in time (Figure 5A). The mean fold increase in TGF $\beta 1$ protein at 15', 30 ', $1 \mathrm{~h}, 3 \mathrm{~h}$ and $7 \mathrm{~h}$ post irradiation was $1.78 \pm 0.28$, $2.16 \pm 0.19,2.19 \pm 0.28,2.51 \pm 0.33$, and $4.03 \pm 0.48$, respectively, compared with that observed in nonirradiated cells $0.71 \pm 0.06$ (Figure 5B). Connective tissue growth factor (CTGF) involves cell migration, proliferation, adhesion and matrix production and it functions mainly as a downstream mediator of TGF $\beta 1$ signaling pathway [36]. As there was marked elevation of TGF $\beta 1$, we next evaluated the level of CTGF in alveolar epithelial cells upon irradiation. Western blot analysis and densitometric quantification of CTGF, in support of other studies, indicated that the protein levels
A)

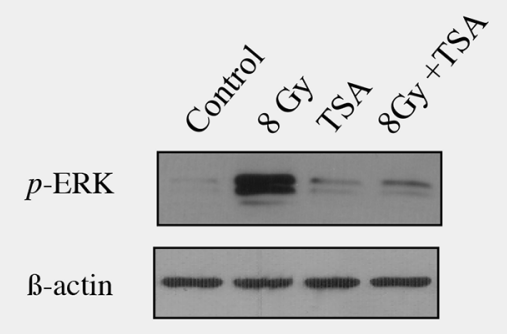

C)

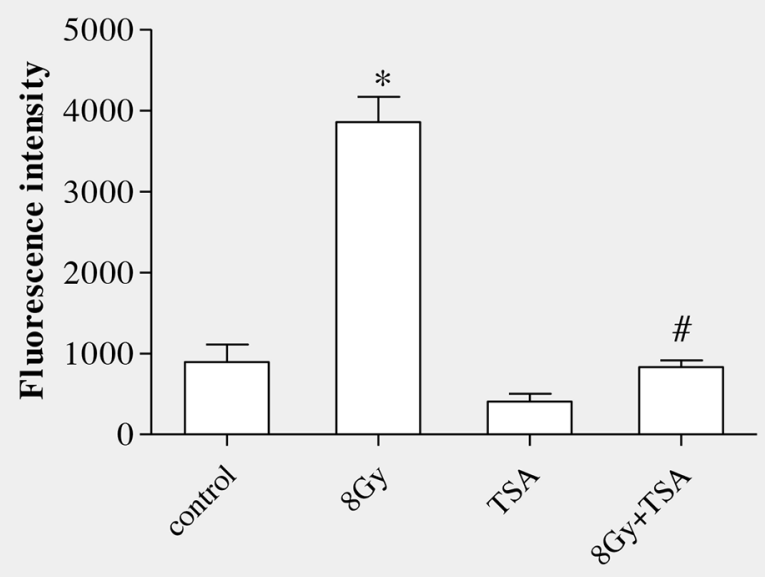

B)

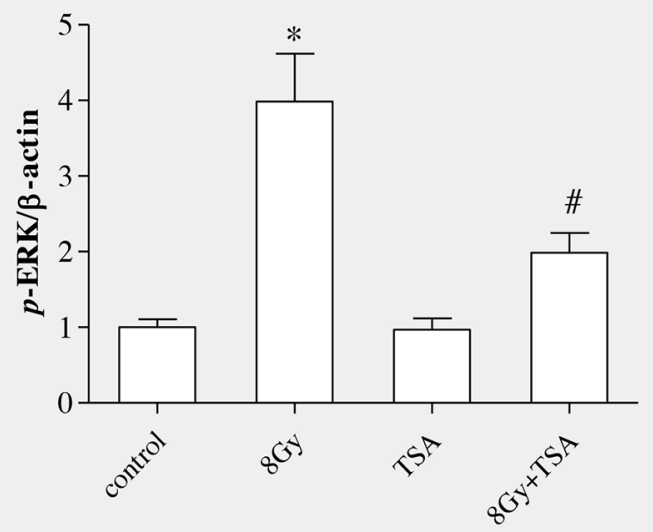

Figure 3: TSA inhibited radiation-induced ERK activation and ROS production in RLE-6TN cells. (A) Western blot analysis of phosphorylation of p44/42ERK at 15 mins following treatment with irradiation and/or $100 \mathrm{nM}$ TSA. TSA pretreatment abolished the radiation-induced increase in the level of $p$-ERK in RLE-6TN cells. (B) Shows the densitometric quantification of p44/42ERK; data are mean \pm SEM; $\mathrm{n}=3$; $^{*} p<0.05$ vs. non-irradiated control; ${ }^{*} \mathrm{p}<0.05$ vs. irradiated control. (C) ROS generation in RLE-6TN cells were determined using DCFH-DA assay, expressed as fluorescence intensity. TSA prevented radiation-induced ROS generation in RLE-6TN cells. Results are means S.E.M for at least three separate experiments. ${ }^{*} p<0.05$ vs. non-irradiated control; ${ }^{*} \mathrm{p}<0.05$ vs. irradiated group. 
of CTGF were increased gradually similar to the TGF $\beta 1$ in irradiated cells (Figure 5A and 5B).

In order to test whether TSA had impact on radiation-induced upregulation of TGF- $\beta 1$ and CTGF, alveolar epithelial cells were incubated with TSA for two hour and exposed to radiation The results showed that TSA partially decreased the levels of TGF $\beta 1$ and CTGF in irradiated alveolar epithelial cells (Figure 5C and 5D). TSA alone did not alter the TGF- $\beta 1$ and CTGF protein levels in alveolar epithelial cells.

\section{Incubation of SB431542, a TGF $\beta$ inhibitor, prevented EMT in irradiated epithelial cells}

To know if TGF $\beta 1$ plays a crucial role in radiationinduced alveolar EMT, TGF inhibitor SB431542 (10 $\mu \mathrm{M})$ was incubated for 2 hours in RLE6TN cells and exposed to radiation (8Gy) and EMT related proteins were analyzed. Western blot analysis on pGSK-3 $\beta$ (Ser9), Snail and a-SMA proteins showed that addition of the TGF- $\beta 1$ receptor inhibitor, SB431542 significantly blocked the radiation-induced GSK-3 $\beta$ phosphorylation at serine 9; whereas there was a partial decrease in the Snail protein in irradiated rat alveolar epithelial cells (Figure 6A). Moreover, inhibition of TGF- $\beta$ by SB-431542 also reduced the radiation-induced increase of a-SMA (Figure 6B). Our results demonstrate that inhibition of TGF $\beta 1$ effectively prevented the transition of epithelial cell to mesenchymal cells and it showed that TGF signalling, at least in part, is necessary for radiation-induced EMT.

\section{ROS scavenging decreased radiation-induced upregulation of TGF $\beta 1$ in alveolar epithelial cells}

Studies have shown that ROS converts the latent form of TGF $\beta$ in to active form, therefore inhibition or neutralization of ROS can decrease TGF $\beta$ activity [37]. We have reported radiation-induced generation of ROS in various cells $[26,38]$. To determine whether ROS can stimulate TGF $\beta 1$ production in irradiated alveolar epithelial cells, N-acetyl-L-cysteine (5mM, NAC), was incubated for $4 \mathrm{~h}$ and then exposed to radiation (8Gy). Pre-incubating cells with NAC blocked radiation-induced ROS generation as described in our previous study [13]. Western blot analysis and densitometric quantification of three independent samples showed that inhibition of radiation-induced ROS production

A
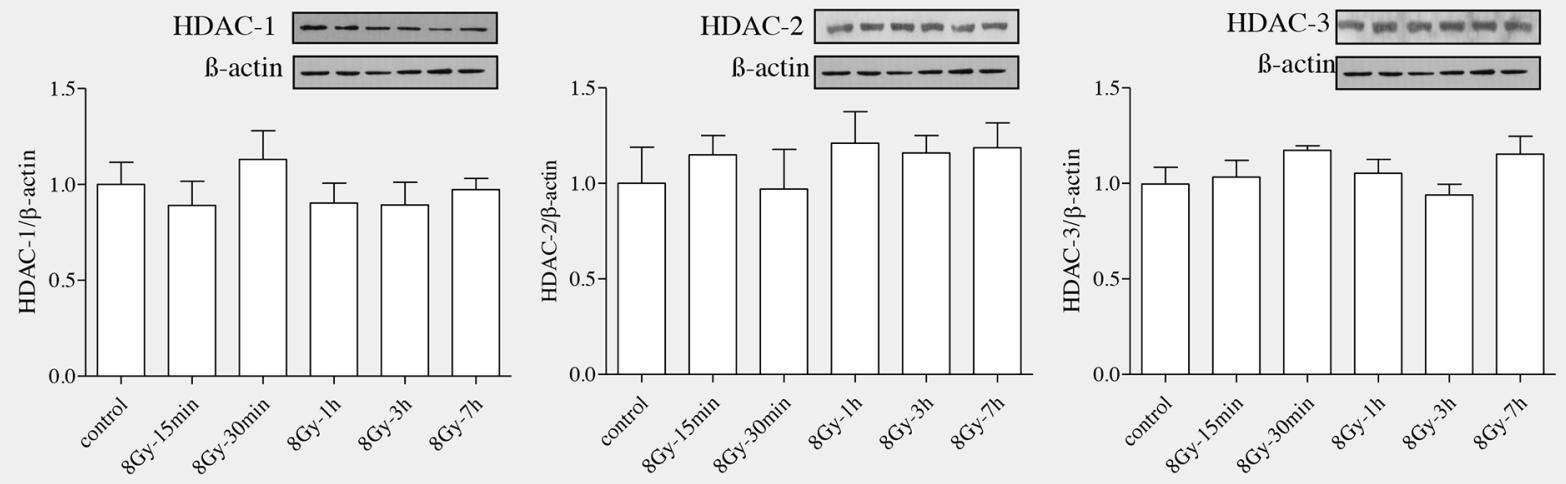

B
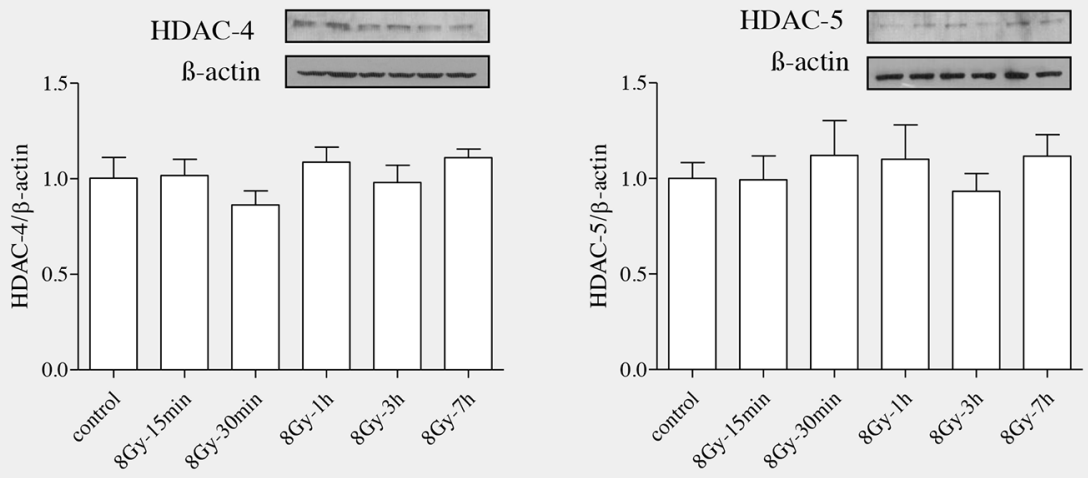

Figure 4: Radiation unaltered the levels of HDAC proteins in RLE-6TN cells. RLE-6TN cells were irradiated with 8 Gy of ${ }^{137} \mathrm{Cs} \gamma$ rays and protein samples were collected at various time points after irradiation for HDACs (1-6). (A) Shows representative blot of HDACs (1-6) levels determined using Western blot. (B) Shows densitometric quantification of HDACs; data are mean \pm SEM; $\mathrm{n}=3$; ${ }^{*} p$ $<0.05$ vs. non-irradiated control. 
with NAC had effectively reduced the formation of TGF $\beta 1$ in the irradiated cells as shown in (Figure 7A and 7B).

The data clearly showed that radiation, by enhancing ROS, stimulates TGF $\beta 1$ formation which promotes the transition of epithelial cells to undergo mesenchymal characteristics. The effect of TSA was not only tested in irradiated RLE-6TN cells, but also confirmed in another cell line, alveolar epithelial cells (A549). Western blot analysis showed that preincubation of TSA at the dose of 100nM inhibited pERK, Snail-1 and N-cadherin and also improved E-cadherin levels in irradiated A549 cells as shown in Figure 8.

\section{DISCUSSION}

Tissue fibrosis is an important cause for morbidity and mortality worldwide. Fibrosis occurs by increased proliferation of fibroblast and myofibroblast. EMT acts as an intermediatory process during tissue fibrogenesis [39]. Previously, we have reported that radiation can induced EMT in type II alveolar epithelial cells and also in irradiated FVBN mice lungs[12,13]. Therefore, inhibition of EMT might be a rational strategy in intervention of lung fibrosis. Recently, histone deacetylase (HDAC) inhibitors receive lot of researchers' attention because of its anticancer and antifibrotic potentials in experimental models of cancers and in recent years the applicability of HDAC inhibitors for the treatment of fibrotic disorders has been explored [40].

A HDAC inhibitor, trichostatin A (TSA) has pleiotropic effects targeting key pathological processes including inflammation, proliferation, angiogenesis and fibrosis [41]. In our study, we demonstrate that TSA effectively decreased radiation-induced EMT by blocking ROS/MEK/ERK/GSK3 $\beta /$ Snail signaling pathway and we also elucidate ROS/TGF $\beta 1$ signaling mechanism also plays a vital role in radiation induced EMT.

EMT is a process whereby epithelial cells lose its cell to cell contact and gradually loses its epithelial marker and enhance the expression of mesenchymal components [42]. From our morphological study, we observed that radiation stimulated lose of cuboidal nature of type II alveolar epithelial cells and exhibited spindle shaped mesenchymal morphology. On the other hand this transition was effectively blocked by administration of TSA in irradiated alveolar epithelial cells showing
$\mathbf{A}$

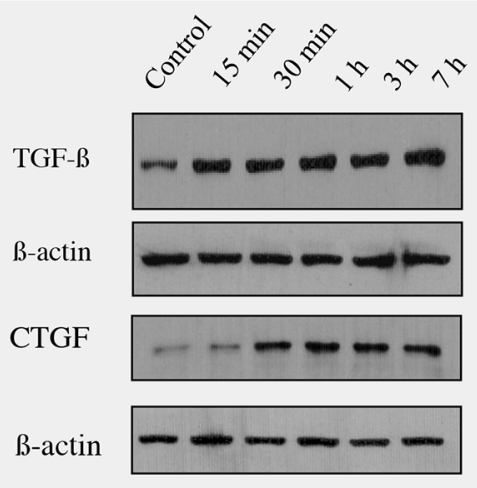

C

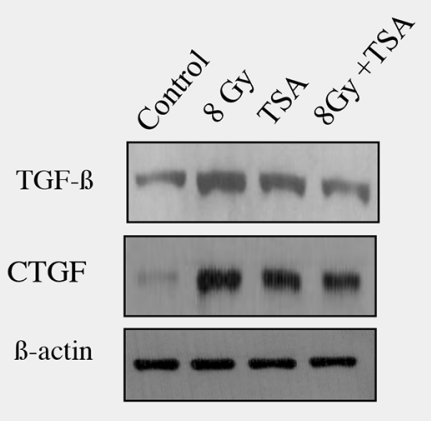

B
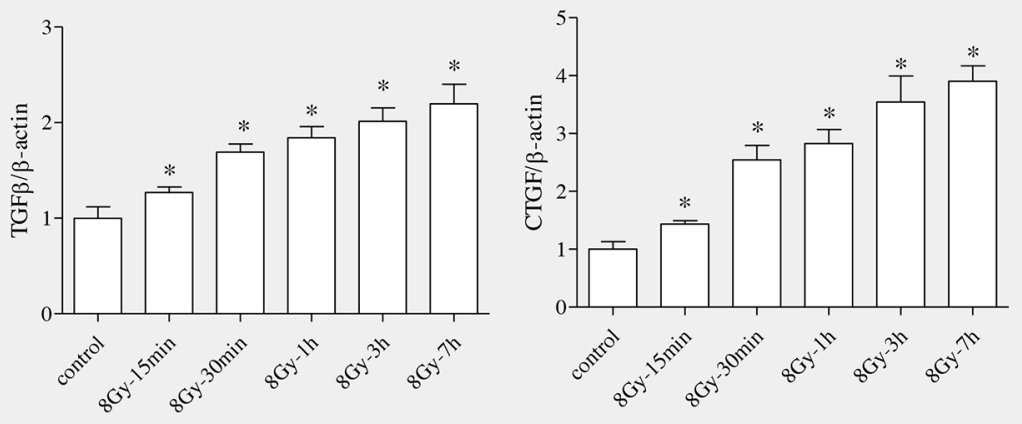

D

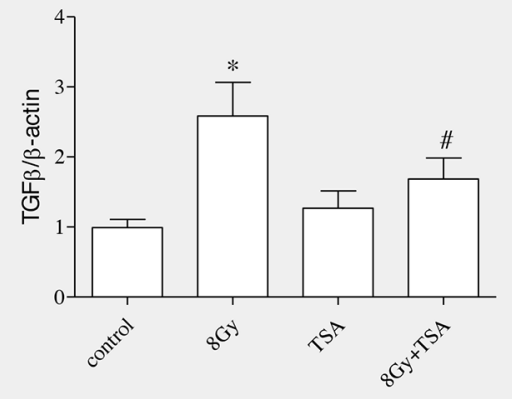

Figure 5: TSA inhibited radiation-induced increase in the protein levels of TGF- $\beta$ and CTGF in RLE-6TN cells. RLE-6TN cells were irradiated with 8 Gy of ${ }^{137} \mathrm{Cs} \gamma$ rays and protein samples were collected at various time points after irradiation. (A) Shows representative blot of TGF $\beta 1$ and CTGF levels determined using Western blot. (B) Shows densitometric quantification of TGF $\beta 1$ and CTGF; data are mean $\pm \mathrm{SEM} ; \mathrm{n}=3 ;{ }^{*} p<0.05$ vs. non-irradiated control. (C) RLE-6TN cells were incubated with/without TSA for 2 $\mathrm{h}$ prior to irradiation with $8 \mathrm{~Gy}$ of ${ }^{137} \mathrm{Cs} \gamma$ rays. Cell lysates were collected and protein levels of TGF $\beta 1$ and CTGF at $7 \mathrm{~h}$ post-irradiation were measured using Western blot (C and D). Results are means S.E.M for at least three separate experiments. ${ }^{*} p<0.05$ vs. non-irradiated control; ${ }^{*} \mathrm{p}<0.05$ vs. irradiated group. 
inhibitory potential of TSA. E-cadherin, a cell adhesion molecule of epithelial cells, gradually lose its expression during EMT which is an important hall mark of EMT process.

Additionally, $\alpha$-smooth muscle actin ( $\alpha$-SMA) has been extensively studied during EMT as it is an important myofibroblast marker and shown to increase markedly in epithelial cells that undergo transition [43]. Following the morpholgical observations, we analyzed the expression of both E-cadherin (epithelial marker) and $\alpha$-SMA in RLE-6TN cells and data suggested that TSA could effectively alter EMT by preserving the expression of E-cadherin and inhibiting $\alpha$-SMA. TSA was also reported to preserve the membrane localization of E-cadherin and inhibited vimentin, an intermediate filament, during TGF $\beta 1$-induced EMT in hepatocytes [44]. In retinal pigment epithelium cells, TSA prevented
TGF $\beta 2$-induced morphological changes and upregulated the expression of $\alpha$-SMA, collagen type I \& IV, fibronectin (mesenchymal marker) and transcription factor including snail and slug [45].

Snail, a zinc finger transcription factor, function mainly acts as a repressor of E-cadherin expression, thereby stimulate the transition of epithelial cells [46]. In our study, western blot and immunofluorescence assays showed that radiation can effectively stimulate Snail expression and enhance nuclear translocation of Snail protein where it acts as a repressor E-cadherin, while TSA administration downregulated Snail which in turn inhibits EMT in alveolar epithelial cells. It was shown that treatment with TSA is sufficient to block the repressor effect of Snail in kidney epithelial cells [47]. TSA was reported to downregulate epithelial marker and up regulate mesenchymal marker via targeting Snail-1 and it has been suggested that in human

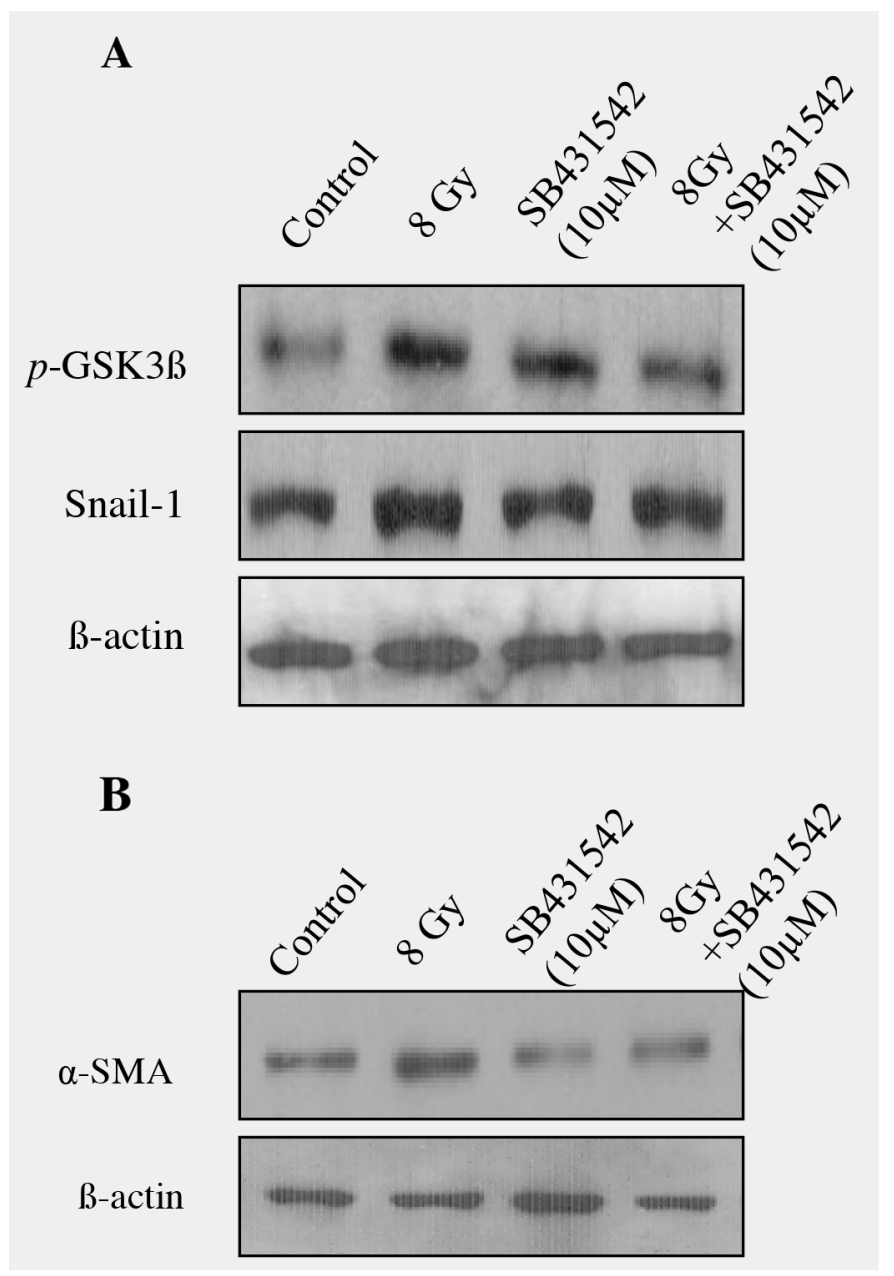

Figure 6: Blocking of TGF- $\beta$ signaling with SB-431542 decreased radiation -induced EMT in RLE-6TNcells. (A) RLE$6 \mathrm{TN}$ cells were treated SB-431542 (SB) for 2 hour prior to radiation. Cell lysates collected at different time intervals were analyzed by Western blot analysis with anti-GSK (pSer9), Snail and a-SMA antibody. An equal amount of protein loading was measured with $\beta$-actin. (B) Densitometric quantification showed that blocking of TGF- $\beta$ signaling with SB-431542 partially reduced radiation-induced EMT in RLE-6TN cells and data are representative of 3 independent experiments. Data are mean $\pm \mathrm{SEM} ; \mathrm{n}=3 ;{ }^{*} p<0.05 v s$. non-irradiated control; ${ }^{\#} p<0.05$ vs. irradiated group. 
mammary epithelial cells, TSA can effectively inhibit induction and also maintenance of EMT [48].

Glycogen synthase kinase-3 beta (GSK3 $\beta$ ), a serine/ threonine kinase is active in resting epithelial cells and is necessary to maintain epithelial architecture [49]. In normal cells, GSK3 $\beta$ inhibit snail by phosphorylating it; however, in EMT process GSK3 $\beta$ activity is inhibited which leads to upregulation of Snail and thereby decreases expression

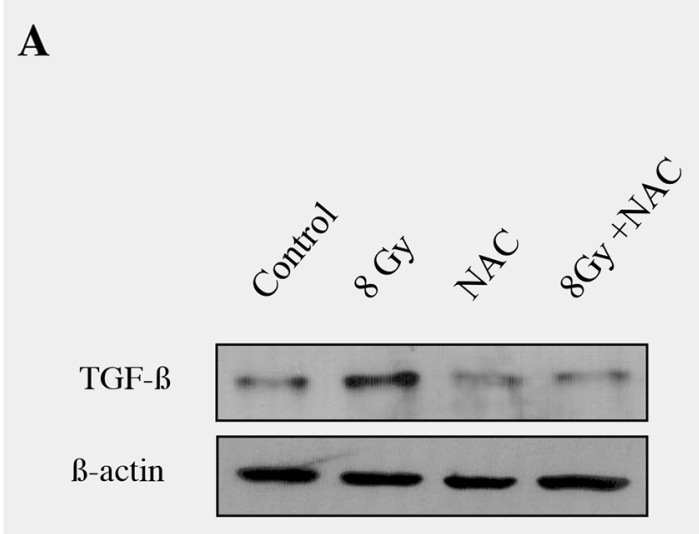

B

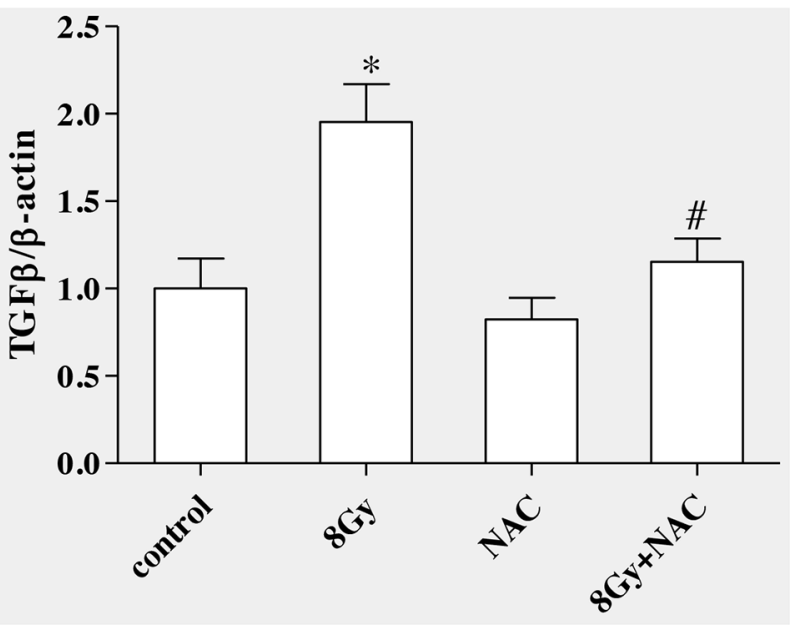

Figure 7: ROS scavenging decreased radiation-induced TGF- $\beta 1$ level in RLE-6TN cells. RLE-6TN cells were incubated with/without NAC $(5 \mathrm{mM})$ for $4 \mathrm{~h}$ prior to irradiation with $8 \mathrm{~Gy}$. The protein level of TGF- $\beta 1$ was determined in the cell lysate at $7 \mathrm{~h}$ postirradiation. (A) Shows representative blot of TGF- $\beta 1$. Decreasing ROS production reduced the protein level of TGF- $\beta 1$ in irradiated RLE-6TN cells. (B) Shows the densitometric quantification of three independent samples. The results are mean $\pm \mathrm{SEM} ; \mathrm{n}=3$; ${ }^{*} p<0.05$ $v s$. non-irradiated control; ${ }^{\#} p<0.05$ vs. irradiated group.

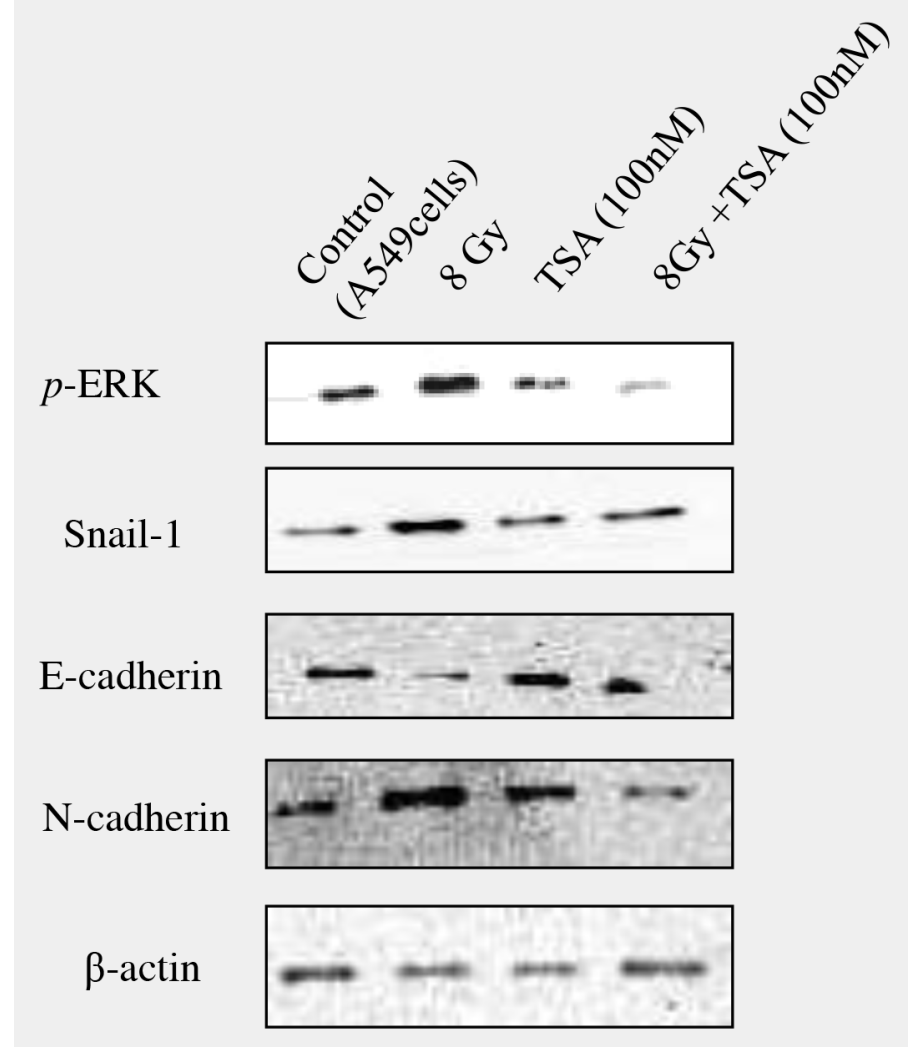

Figure 8: Effect of TSA on irradiated A549 cells. In order to confirm the inhibitory effect of TSA on radiation-induced EMT, the effect was tested using A549 cells, a model to study the EMT. TSA (100nM) was incubated 2 hours prior to radiation and western blot analysis on pERK, Snail-1, E-cadherin, N-cadherin was performed and representative blots were shown in the Figure 8. 
of E-cadherin [50]. Previously, we reported that radiation enhance GSK3 $\beta$ phosphorylation at serine 9 which prevent its binding efficiency with Snail and facilitate nuclear translocation of Snail [13]. In this study, we observed that TSA decreased the expression of inactive form of GSK3 $\beta$ which might prevent Snail activation and thereby inhibiting EMT in lung epithelial cells. GSK $3 \beta$ inactivation is stimulated by various upstream signalling pathways including WNT, PI3k/AKT and MAPK [51-53]. Our previous investigation on MAPK to radiation in RLE-6TN cells showed that among other kinases, ERK1/2 signaling involves mainly in deactivating GSK $3 \beta$ via phosphorylation [13]. In this study, the phosphorylation of ERK1/2 in RLE6TN cells was inhibited by TSA, indicating that TSA administration suppresses ERK/GSK3 $\beta /$ Snail/E-cadherin pathway leading to inhibition of radiation-induced of EMT in irradiated alveolar epithelial cells.
In lung, increased oxidative stress leads to cell damage and triggers inflammation and finally lead to fibrosis [54]. The biological effect of ionizing radiation is mainly caused by formation reactive oxygen species (ROS) which triggers oxidative damage to protein, lipids, DNA and alters signaling pathways [55]. In renal tubular epithelial cells, ROS mediates TGF $\beta 1$-induced EMT by mainly activating MAPK [56]. We have shown that ROS activate $\mathrm{MEK} / \mathrm{ERK}$ signaling in irradiated alveoloar epithelial cells [13].

Our current data provide the first evidence that TSA effectively blocked radiation-induced ROS in lung alveolar epithelial cells and thereby, prevented transition of epithelial cells into mesenchymal phenotype. Yang et al., [57] have reported that TSA can scavenge free radicals and alters Nrf2-ARE signaling in TGF $\beta$ induced myofibroblast differentiation. TSA, by acting

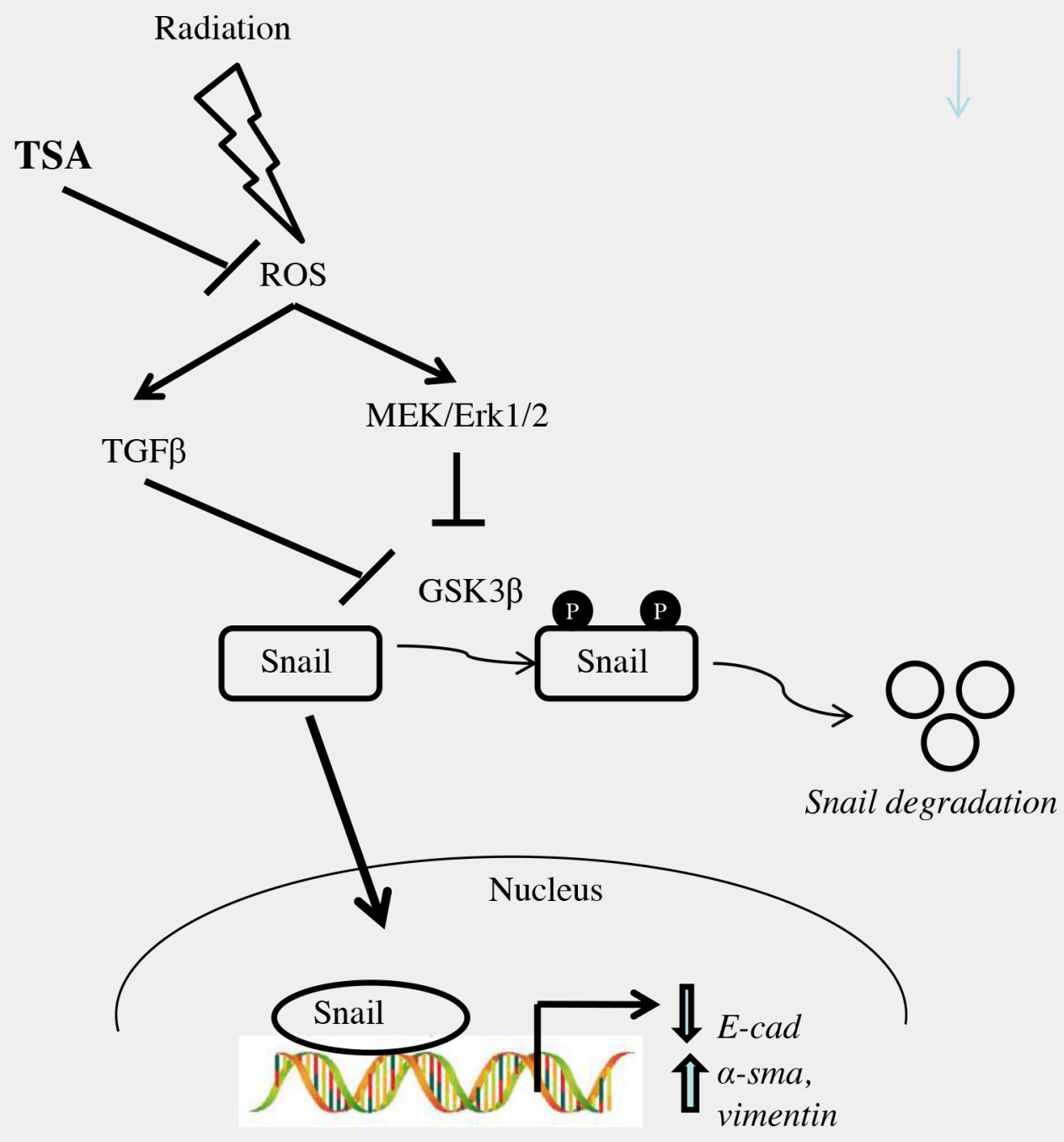

Figure 9: Schematic representation of the proposed mechanism for effect of TSA on radiation-induced EMT in alveolar type II epithelial cells. TSA, at least in part, might prevent radiation-induced EMT by blocking i) ROS/MEK/ERK ii) ROS/TGF- $\beta 1$ signaling pathways in RLE-6TN cells. 
an antioxidant reduces EtOH-induced oxidative stress in the human neuronal cell line [58]. As TSA is a specific inhibitor of HDAC activity (Class I and Class II), we next examined whether HDAC proteins are involved in radiation induced alveolar epithelial to mesenchymal transition. Our findings on time dependent response of HDAC proteins showed that radiation did not alter the protein levels of HDAC in RLE-6TN cells, thus we now show for the first time that TSA exerts anti-EMT effect in irradiated RLE-6TN cells mainly by inhibiting radiationinduced ROS production and preventing the propagation of $\mathrm{MEK} / \mathrm{ERK}$ signaling.

TGF $\beta$ is regarded as a key mediator of fibrosis. Epithelial cells derived from a variety of tissues including lung, kidney and breast [59-61] display myofibroblast features following exposure to TGF $\beta$. TGF $\beta$, a central mediator of fibrosis, controls EMT by a network of signaling and transcriptional events $[9,10]$. TGF $\beta$ is known to directly induce EMT in pulmonary adenocarcinoma cell and also in primary type II epithelial cells [34]. TGF- $\beta 1$ has been described as the main CTGF inducer [62]. CTGF is a secreted matricellular protein that has been implicated as a regulator of cellular proliferation, angiogenesis and remodeling of the extracellular matrix [63]. CTGF has recently received much attention as a novel profibrotic factor and plays important role in fibrosis and in various diseases including radiation enteritis [64]. In vitro studies in lung epithelial cells showed an increased expression of EMT-associated proteins due to blocking of exogenous TGF $\beta$ by knocking-down of CTGF, suggesting that CTGF is a mediator in TGF $\beta$-induced EMT [65]. The main finding of our study showed that radiation enhanced the protein levels in both TGF $\beta$ and CTGF gradually with increase in the time; whereas TSA inhibited the expression of both proteins in alveolar epithelial cells. Yoshikawa et al., [66] have reported that TSA prevented TGF- $\beta 1-$ induced EMT in human renal proximal tubular epithelial cells. In our study, inhibition of TGF $\beta$ using SB431542 inhibited the protein levels of GSK $3 \beta$, snail and $\alpha$-SMA, implying that TGF $\beta$ is required for radiation-induced EMT.

ROS generated by ionising radiation has been shown to play a crucial role in development of fibrosis. One of the possible mechanisms whereby ROS induce fibrosis is targeting TGF $\beta$. Increased ROS formation would convert latent form of TGF- $\beta$ to active form and also stimulate the expression and secretion of TGF $\beta$ in many types of cells $[37,67]$. In another study, ROS generated by xanthine/ xanthine oxidase system was shown to increase TGF $\beta$ expression in human alveolar epithelial cells [68]. In our study, suppression of ROS production with antioxidant (NAC) lead to inhibition of TGF $\beta$ in irradiated alveolar epithelial cells, suggesting that ROS is necessary to stimulate TGF $\beta$ which mediates transition of epithelial cells.
In summary, our results showed that TSA inhibits EMT in irradiated alveolar epithelial cells (Figure 9). The inhibitory mechanism of TSA in irradiated alveolar epithelial cells is due to inactivation of ROS/MEK/ERK signaling. In addition, the results showed that radiation exposure leads to increased generation of ROS, which would active TGF $\beta$. Meanwhile, TSA administration attenuated ROS/TGF $\beta$ signalling in radiation-induced alveolar EMT. However, the role of TGF $\beta /$ smad signaling and CTGF are still unclear in irradiated alveolar epithelial cells. Additional studies on TGF $\beta /$ smad and CTGF are needed to fully understand their effects on radiation induced EMT and also upon TSA treatment, which help to understand the therapeutic efficacy of TSA on lung fibrosis.

\section{MATERIALS AND METHODS}

\section{Cell culture}

RLE-6TN cells, a rat alveolar type II epithelial cell line, was obtained from ATCC (Manassas, VA) and routinely maintained in Dulbecco's Modified Eagle Medium (DMEM) containing $10 \%$ fetal bovine serum, $2 \mathrm{mM}$ L-glutamine, $100 \mathrm{IU} / \mathrm{mL}$ penicillin and $100 \mu \mathrm{g} / \mathrm{mL}$ streptomycin (purchased from Invitrogen, Carlsbad, CA) at $37^{\circ} \mathrm{C}$ with $5 \% \mathrm{CO} 2$ in air.

\section{Irradiation and TSA treatment}

Once cells reached $>80 \%$ confluence, the DMEM medium was replaced with serum-free medium for $24 \mathrm{~h}$ prior to irradiation. Cells were then irradiated with a single dose of 8 Gy $\gamma$ rays using a $137 \mathrm{Cs}$ irradiator at a dose rate of $3.64 \mathrm{~Gy} / \mathrm{min}$. All irradiations were performed at room temperature. To analyse the effect of TSA (Sigma-Aldrich, St. Louis, MO), TSA at a final concentration of $100 \mathrm{nM}$ was added to the culture and incubated for two hours prior to radiation at the dose of $8 \mathrm{~Gy}$.

\section{Western blot analysis}

RLE-6TN cells were lysed using RIPA buffer containing $1 \mathrm{~m} M$ PMSF, $1 \mu \mathrm{g} / \mathrm{mL}$ aprotinin, $1 \mu \mathrm{g} / \mathrm{mL}$ leupeptin, $1 \mathrm{mM} \mathrm{Na} \mathrm{VO}_{4}$ and $1 \mathrm{mM} \mathrm{NaF}$, and stored in aliquots at $-80^{\circ} \mathrm{C}$ until further analysis. The lysate $(20$ $\mu \mathrm{g})$ was mixed with an equal volume of sample buffer, denatured by boiling, and then separated on $10-15 \%$ polyacrylamide mini-gel. The proteins were transferred to nitrocellulose membranes (Amersham, Arlington Heights, IL), blocked with 5\% milk and incubated overnight with E-cadherin (Abcam, Cambridge, MA), Snail (Abcam), p-GSK3 $\beta$ (s9) (Cell Signaling Technology, Danvers, MA), GSK3 $\beta$ (Cell Signaling Technology), a-SMA (Abcam), phosphorylated ERK (Santa Cruz Biotechnology), ERK 
(Santa Cruz Biotechnology), p-p38, p-JNK (Cell Signaling Technology) and $\beta$-actin antibodies (Sigma, St. Louis, MO). The blots were then incubated with anti-mouse or anti-rabbit $\operatorname{IgG}$ horseradish peroxidase conjugated antibodies (GE Healthcare, Piscataway, NJ) for $1 \mathrm{~h}$ at room temperature. Finally, the signal was detected using Amersham ECL plus (GE Healthcare).

\section{Reactive oxygen species (ROS) generation}

ROS generation was measured using 2'7'-dichlorodihydofluorescein diacetate $\left(\mathrm{H}_{2} \mathrm{DCFDA}\right.$, Invitrogen, CA) as described previously [22]. Cells were pre-incubated with TSA for 2 hours followed by 10 $\mu \mathrm{M} \mathrm{H} \mathrm{H}_{2}$ DCFDA (in PBS) treatment for $30 \mathrm{~min}$, washed and then irradiated with 8 Gy of ${ }^{137} \mathrm{Cs} \gamma$ rays; the cells were then returned to the incubator and maintained for $1 \mathrm{~h}$. The fluorescence intensity was then measured at excitation wavelength $485 \mathrm{~nm}$ and emission wavelength $530 \mathrm{~nm}$ using a microplate fluorescence reader (Bio-Tek Instruments Inc., Winooski, VT).

\section{Immunofluorescence staining}

Cells grown on 8-well chamber slides were pretreated with TSA followed by 8 Gy radiation of ${ }^{137} \mathrm{Cs}$ $\gamma$ rays and then fixed with $4 \%$ neutral formalin for 30 minutes. After washing three times with $1 \mathrm{X}$ PBS, the cells were blocked with $3 \%$ BSA for $1 \mathrm{~h}$. The cells were then incubated with Snail (Abcam), antibody at $4{ }^{\circ} \mathrm{C}$ overnight. After washing with PBS, the sections were incubated with Texas Red conjugated anti-rabbit (Vector Laboratories, Burlingame, CA) antibodies at room temperature for 30 min. Nuclei were counterstained with 4'-6-diamidino-2phenylindole (DAPI), and the slides were analyzed using a fluorescence microscope.

\section{Immunoprecipitation}

Five hundred $\mu \mathrm{g}$ of cell lysate were incubated with $10 \mu \mathrm{L}$ of the Snail antibody overnight at $4^{\circ} \mathrm{C}$ in a rotating wheel. After overnight incubation, $50 \mu \mathrm{L}$ of protein $\mathrm{A} / \mathrm{G}$ agarose were added and the solution incubated for $4 \mathrm{~h}$ at $4^{\circ} \mathrm{C}$ with rotation. The complexes were harvested by centrifugation, washed three times with RIPA buffer and then dissociated from the beads by addition of $50 \mu \mathrm{L}$ of SDS sample loading buffer and heated for $5 \mathrm{~min}$ at 95 ${ }^{\circ} \mathrm{C}$. The protein levels of HDACs were analyzed using Western blot.

\section{RT-PCR}

Total RNA was isolated from cells using an RNeasy Mini Kit according to the manufacturer's recommendations (Qiagen, Valencia, CA, USA) with the addition of DNase digestion with an RNase-free DNase set (Qiagen). One microgram of total mRNA was used as template for cDNA synthesis with the FirstStrand cDNA Synthesis Kit (Invitrogen) according to the recommendations of the manufacturer. The PCR amplifications were carried out in $50 \mu \mathrm{l}$ reaction solution containing $2 \mu \mathrm{l}$ of RT product, $5 \mu \mathrm{l}$ of $10 \times$ PCR buffer, 0.15 $\mathrm{mM} \mathrm{MgCl} 2,1 \mu \mathrm{l}$ of $10 \mathrm{mM}$ dNTP, 15 pmol of sense and antisense primers, and $2.5 \mathrm{U}$ Taq polymerase (Promega). The PCR solution was denatured initially at $94{ }^{\circ} \mathrm{C}$ for 2 min, followed by $25-30$ cycles through a 1-min denaturing step at $94{ }^{\circ} \mathrm{C}$, a 40 -s annealing step at $50-55^{\circ} \mathrm{C}$, and a 40 -s elongation step at $72{ }^{\circ} \mathrm{C}$. E-cadherin, $\alpha$-SMA and GAPDH primers were designed and synthesized by Integrated DNA Technologies (Iowa City, IA, USA).

\section{Statistical analysis}

Statistical analysis was performed using one-sample Student's $t$ test to compare the differences between the TSA and irradiated groups. A $p$ value of $\leq 0.05$ was considered significant.

\section{ACKNOWLEDGMENTS}

Kenneth T. Wheeler Jr. for his advice and support in this study.

\section{CONFLICTS OF INTEREST}

No conflicts of interest.

\section{FUNDING}

The grant 1U19A1091036-01 (PI Jaquellina P Williams) and SERB-DST (YSS/2014/000518, Devipriya Nagarajan - PI, India).

\section{REFERENCES}

1. Kong FM, Ten Haken R, Eisbruch A, Lawrence TS. Nonsmall cell lung cancer therapy-related pulmonary toxicity: an update on radiation pneumonitis and fibrosis. Semin Oncol. 2005; 32:S42-54.

2. Tsoutsou PG, Koukourakis MI. Radiation pneumonitis and fibrosis: mechanisms underlying its pathogenesis and implications for future research. Int J Radiat Oncol Biol Phys. 2006; 66:1281-1293.

3. Radisky DC. Epithelial-mesenchymal transition. J Cell Sci. 2005; 118:4325-4326.

4. Willis BC, duBois RM, Borok Z. Epithelial origin of myofibroblasts during fibrosis in the lung. Proc Am Thorac Soc. 2006; 3:377-382. 
5. Balli D, Ustiyan V, Zhang Y, Wang IC, Masino AJ, Ren X, Whitsett JA, Kalinichenko VV, Kalin TV. Foxm1 transcription factor is required for lung fibrosis and epithelial-to-mesenchymal transition. EMBO J. 2013; 32:231-244.

6. Hinz B, Phan SH, Thannickal VJ, Galli A, Bochaton-Piallat ML, Gabbiani G. The myofibroblast: one function, multiple origins. Am J Pathol. 2007; 170:1807-1816.

7. Mohamet L, Hawkins K, Ward CM. Loss of function of e-cadherin in embryonic stem cells and the relevance to models of tumorigenesis. J Oncol. 2011; 2011:352616.

8. Yang Z, Rayala S, Nguyen D, Vadlamudi RK, Chen S, Kumar R. Pak1 phosphorylation of snail, a master regulator of epithelial-to-mesenchyme transition, modulates snail's subcellular localization and functions. Cancer Res. 2005; 65:3179-3184.

9. Chapman HA. Epithelial-mesenchymal interactions in pulmonary fibrosis. Annu Rev Physiol. 2011; 73:413-435.

10. Thiery JP, Sleeman JP. Complex networks orchestrate epithelial-mesenchymal transitions. Nature rev Mol cell biol. 2006; 72:131-142.

11. Zavadil J, Bottinger EP. TGF-beta and epithelial-tomesenchymal transitions. Oncogene. 2005; 24:5764-5774.

12. Almeida C, Nagarajan D, Tian J, Leal SW, Wheeler K, Munley M, Blackstock W, Zhao W. The role of alveolar epithelium in radiation-induced lung injury. PloS one. 2013; 8:e53628.

13. Nagarajan D, Melo T, Deng Z, Almeida C, Zhao W. ERK/ GSK3beta/Snail signaling mediates radiation-induced alveolar epithelial-to-mesenchymal transition. Free Radic biol \& med. 2012; 52:983-992.

14. Glenisson W, Castronovo V, Waltregny D. Histone deacetylase 4 is required for TGFbetal-induced myofibroblastic differentiation. Biochim Biophys Acta. 2007; 1773:1572-1582.

15. Yoshida M, Kijima M, Akita M, Beppu T. Potent and specific inhibition of mammalian histone deacetylase both in vivo and in vitro by trichostatin A. The Journal of biological chemistry. 1990; 265:17174-17179.

16. Chung YL, Wang AJ, Yao LF. Antitumor histone deacetylase inhibitors suppress cutaneous radiation syndrome: Implications for increasing therapeutic gain in cancer radiotherapy. Mol Cancer Ther. 2004; 3:317-325.

17. Williams RJ. Trichostatin A, an inhibitor of histone deacetylase, inhibits hypoxia-induced angiogenesis. Expert Opin Investig Drugs. 2001; 10:1571-1573.

18. Rombouts K, Niki T, Wielant A, Hellemans K, Geerts A. Trichostatin A, lead compound for development of antifibrogenic drugs. Acta Gastroenterol Belg. 2001; 64:239-246.

19. Rombouts K, Niki T, Greenwel P, Vandermonde A, Wielant A, Hellemans K, De Bleser P, Yoshida M, Schuppan D, Rojkind M, Geerts A. Trichostatin A, a histone deacetylase inhibitor, suppresses collagen synthesis and prevents TGFbeta(1)-induced fibrogenesis in skin fibroblasts. Exp Cell Res. 2002; 278:184-197.

20. Niki T, Rombouts K, De Bleser P, De Smet K, Rogiers V, Schuppan D, Yoshida M, Gabbiani G, Geerts A. A histone deacetylase inhibitor, trichostatin A, suppresses myofibroblastic differentiation of rat hepatic stellate cells in primary culture. Hepatology. 1999; 29:858-867.

21. Chen X, Xiao W, Chen W, Luo L, Ye S, Liu Y. The epigenetic modifier trichostatin A, a histone deacetylase inhibitor, suppresses proliferation and epithelialmesenchymal transition of lens epithelial cells. Cell Death Dis. 2013; 4:e884.

22. Zhao W, Spitz DR, Oberley LW, Robbins ME. Redox modulation of the pro-fibrogenic mediator plasminogen activator inhibitor-1 following ionizing radiation. Cancer Res. 2001; 61:5537-5543.

23. Zhou BP, Deng J, Xia W, Xu J, Li YM, Gunduz M, Hung MC. Dual regulation of Snail by GSK-3beta-mediated phosphorylation in control of epithelial-mesenchymal transition. Nat Cell Biol. 2004; 6:931-940.

24. Elyaman W, Terro F, Wong NS, Hugon J. in vivo activation and nuclear translocation of phosphorylated glycogen synthase kinase-3beta in neuronal apoptosis: links to tau phosphorylation. Eur J Neurosci. 2002; 15:651-660.

25. Bachelder RE, Yoon SO, Franci $\mathrm{C}$, de Herreros AG, Mercurio AM. Glycogen synthase kinase-3 is an endogenous inhibitor of Snail transcription: implications for the epithelial-mesenchymal transition. J Cell Biol. 2005; 168:29-33.

26. Zhao W, Robbins ME. Inflammation and chronic oxidative stress in radiation-induced late normal tissue injury: therapeutic implications. Curr Med Chem. 2009; 16:130-43.

27. Thiagalingam S, Cheng $\mathrm{KH}$, Lee HJ, Mineva N, Thiagalingam A, Ponte JF. Histone deacetylases: unique players in shaping the epigenetic histone code. Ann N Y Acad Sci. 2003; 983:84-100.

28. Acharya MR, Sparreboom A, Venitz J, Figg WD. Rational development of histone deacetylase inhibitors as anticancer agents: a review. Mol Pharmacol. 2005; 68:917-932.

29. Glozak MA, Sengupta N, Zhang X, Seto E. Acetylation and deacetylation of non-histone proteins. Gene. 2005; 363:15-23.

30. Fischle W, Dequiedt F, Hendzel MJ, Guenther MG, Lazar MA, Voelter W, Verdin E. Enzymatic activity associated with class II HDACs is dependent on a multiprotein complex containing HDAC3 and SMRT/N-CoR. Mol Cell. 2002; 9:45-57.

31. Dokmanovic M, Marks PA. Prospects: histone deacetylase inhibitors. J Cell Biochem. 2005; 96:293-304.

32. Miettinen PJ, Ebner R, Lopez AR, Derynck R. TGF-beta induced transdifferentiation of mammary epithelial cells to 
mesenchymal cells: involvement of type I receptors. J Cell Biol. 1994; 127:2021-2036.

33. Fan JM, Ng YY, Hill PA, Nikolic-Paterson DJ, Mu W, Atkins RC, Lan HY. Transforming growth factor-beta regulates tubular epithelial-myofibroblast transdifferentiation in vitro. Kidney Int. 1999; 56:1455-1467.

34. Kasai H, Allen JT, Mason RM, Kamimura T, Zhang Z. TGFbetal induces human alveolar epithelial to mesenchymal cell transition (EMT). Respir Res. 2005; 6:56.

35. Saika S, Kono-Saika S, Ohnishi Y, Sato M, Muragaki Y, Ooshima A, Flanders KC, Yoo J, Anzano M, Liu CY, Kao WW, Roberts AB. Smad3 signaling is required for epithelial-mesenchymal transition of lens epithelium after injury. Am J Pathol. 2004; 164:651-663.

36. Tachaudomdach C, Kantachuvesiri S, Changsirikulchai S, Wimolluck S, Pinpradap K, Kitiyakara C. Connective tissue growth factor gene expression and decline in renal function in lupus nephritis. Exp Ther Med. 2012; 3:713-718.

37. Amarnath S, Dong L, Li J, Wu Y, Chen W. Endogenous TGF-beta activation by reactive oxygen species is key to Foxp3 induction in TCR-stimulated and HIV-1-infected human CD4+CD25- T cells. Retrovirology. 2007; 4:57.

38. Zhao W, Goswami PC, Robbins ME. Radiation-induced up-regulation of Mmp2 involves increased mRNA stability, redox modulation, and MAPK activation. Radiat Res. 2004; 161:418-429.

39. Lee K, Nelson CM. New insights into the regulation of epithelial-mesenchymal transition and tissue fibrosis. Int Rev Cell Mol Biol. 2012; 294:171-221.

40. Van Beneden K, Mannaerts I, Pauwels M, Van den Branden C, van Grunsven LA. HDAC inhibitors in experimental liver and kidney fibrosis. Fibrogenesis \&Tissue Repair. $2013 ; 6: 1$.

41. Royce SG, Dang W, Yuan G, Tran J, El-Osta A, Karagiannis TC, Tang ML. Effects of the histone deacetylase inhibitor, trichostatin A, in a chronic allergic airways disease model in mice. Arch Immunol Ther Exp (Warsz). 2012; 60:295-306.

42. Yang J, Weinberg RA. Epithelial-mesenchymal transition: at the crossroads of development and tumor metastasis. Dev Cell. 2008; 14:818-829.

43. Ohbayashi M, Kubota S, Kawase A, Kohyama N, Kobayashi Y, Yamamoto T. Involvement of epithelialmesenchymal transition in methotrexate-induced pulmonary fibrosis. J Toxicol Sci. 2014; 39:319-330.

44. Kaimori A, Potter JJ, Choti M, Ding Z, Mezey E, Koteish AA. Histone deacetylase inhibition suppresses the transforming growth factor betal-induced epithelial-tomesenchymal transition in hepatocytes. Hepatology. 2010; 52:1033-1045.

45. Xiao W, Chen X, Liu X, Luo L, Ye S, Liu Y. Trichostatin A, a histone deacetylase inhibitor, suppresses proliferation and epithelial-mesenchymal transition in retinal pigment epithelium cells. J cell mol med. 2014; 18:646-655.
46. Yook JI, Li XY, Ota I, Fearon ER, Weiss SJ. Wnt-dependent regulation of the E-cadherin repressor snail. J biol Chem. 2005; 280:11740-11748.

47. Peinado H, Ballestar E, Esteller M, Cano A. Snail mediates E-cadherin repression by the recruitment of the $\operatorname{Sin} 3 \mathrm{~A} /$ histone deacetylase 1 (HDAC1)/HDAC2 complex. Mol Cell Biol. 2004; 24:306-319.

48. Javaid S, Zhang J, Anderssen E, Black JC, Wittner BS, Tajima K, Ting DT, Smolen GA, Zubrowski M, Desai R, Maheswaran S, Ramaswamy S, Whetstine JR, Haber DA. Dynamic chromatin modification sustains epithelialmesenchymal transition following inducible expression of Snail-1. Cell Rep. 2013; 5:1679-1689.

49. Papkoff J, Aikawa M. WNT-1 and HGF regulate GSK3 beta activity and beta-catenin signaling in mammary epithelial cells. Biochem Biophys Res Commun. 1998; 247:851-858.

50. Liu ZC, Chen XH, Song HX, Wang HS, Zhang G, Wang H, Chen DY, Fang R, Liu H, Cai SH, Du J. Snail regulated by $\mathrm{PKC} / \mathrm{GSK}-3 \beta$ pathway is crucial for EGF-induced epithelial-mesenchymal transition (EMT) of cancer cells. Cell Tissue Res. 2014; 358:491-502.

51. Bienz M, Clevers H. Linking colorectal cancer to Wnt signaling. Cell. 2000; 103:311-320.

52. Cross DA, Alessi DR, Cohen P, Andjelkovich M, Hemmings BA. Inhibition of glycogen synthase kinase-3 by insulin mediated by protein kinase B. Nature. 1995; 378:785-789.

53. Ding Q, Xia W, Liu JC, Yang JY, Lee DF, Xia J, Bartholomeusz G, Li Y, Pan Y, Li Z, Bargou RC, Qin J, Lai CC, et al. Erk associates with and primes GSK-3beta for its inactivation resulting in upregulation of betacatenin. Mol Cell. 2005; 19:159-170

54. Graves PR, Siddiqui F, Anscher MS, Movsas B. Radiation pulmonary toxicity: from mechanisms to management. Semin Radiat Oncol. 2010; 20:201-207.

55. Hall EJ, Giaccia AJ. Radiobiology for the Radiologist. 6th. Lippincott Williams \& Wilkins; Philadelphia, PA: 2006.

56. Rhyu DY, Yang Y, Ha H, Lee GT, Song JS, Uh ST, Lee HB. Role of reactive oxygen species in TGF-beta1-induced mitogen-activated protein kinase activation and epithelialmesenchymal transition in renal tubular epithelial cells. J Am Soc Nephrol. 2005; 16:667-675.

57. Yang L, Qu M, Wang Y, Duan H, Chen P, Wang Y, Shi W, Danielson P, Zhou Q. Trichostatin A inhibits transforming growth factor-beta-induced reactive oxygen species accumulation and myofibroblast differentiation via enhanced NF-E2-related factor 2-antioxidant response element signaling. Mol Pharmacol. 2013; 83:671-680.

58. Agudelo M, Gandhi N, Saiyed Z, Pichili V, Thangavel S, Khatavkar P, Yndart-Arias A, Nair M. Effects of alcohol on histone deacetylase 2 (HDAC2) and the neuroprotective role of trichostatin A (TSA). Alcohol Clin Exp Res. 2011; 35:1550-1556. 
59. Zhou B, Buckley ST, Patel V, Liu Y, Luo J, Krishnaveni MS, Ivan M, DeMaio L, Kim KJ, Ehrhardt C, Crandall ED, Borok Z. Troglitazone attenuates TGF-beta1-induced EMT in alveolar epithelial cells via a PPARgamma-independent mechanism. PloS one. 2012; 7:e38827.

60. Elberg G, Chen L, Elberg D, Chan MD, Logan CJ, Turman MA. MKL1 mediates TGF-beta1-induced alpha-smooth muscle actin expression in human renal epithelial cells. Am J Physiol Renal Physiol. 2008; 294:F1116-1128.

61. O'Connor JW, Gomez EW. Cell adhesion and shape regulate TGF-betal-induced epithelial-myofibroblast transition via MRTF-A signaling. PloS one. 2013; 8:e83188.

62. Yokoi H, Sugawara A, Mukoyama M, Mori K, Makino H, Suganami T, Nagae T, Yahata K, Fujinaga Y, Tanaka I, Nakao K. Role of connective tissue growth factor in profibrotic action of transforming growth factor-beta: a potential target for preventing renal fibrosis. Am J Kidney Dis. 2001; 38:S134-138.

63. Friedrichsen S, Heuer H, Christ S, Winckler M, Brauer D, Bauer K, Raivich G. CTGF expression during mouse embryonic development. Cell Tissue Res. 2003; 312:175-188.
64. Abdel Wahab N, Mason RM. Connective tissue growth factor and renal diseases: some answers, more questions. Curr Opin Nephrol Hypertens. 2004; 13:53-58.

65. Sonnylal S, Xu S, Jones H, Tam A, Sreeram VR, Ponticos M, Norman J, Agrawal P, Abraham D, de Crombrugghe B. Connective tissue growth factor causes EMT-like cell fate changes in vivo and in vitro. J Cell Sci. 2013; 126:2164-2175.

66. Yoshikawa M, Hishikawa K, Marumo T, Fujita T. Inhibition of histone deacetylase activity suppresses epithelial-tomesenchymal transition induced by TGF-betal in human renal epithelial cells. J Am Soc Nephrol. 2007; 18:58-65.

67. Shvedova AA, Kisin ER, Murray AR, Kommineni C, Castranova V, Fadeel B, Kagan VE. Increased accumulation of neutrophils and decreased fibrosis in the lung of NADPH oxidase-deficient $\mathrm{C} 57 \mathrm{BL} / 6$ mice exposed to carbon nanotubes. Toxicol Appl Pharmacol. 2008; 231:235-240.

68. Bellocq A, Azoulay E, Marullo S, Flahault A, Fouqueray B, Philippe C, Cadranel J, Baud L. Reactive oxygen and nitrogen intermediates increase transforming growth factorbeta1 release from human epithelial alveolar cells through two different mechanisms. Am J Respir Cell Mol Biol. 1999; 21:128-136. 